\title{
Phenomenology AND ARIStotle's ConCept Of Being-AT-WORK
}

\section{LA FENOMENOLOGÍA Y EL CONCEPTO ARISTOTÉLICO DE ENERGEIA}

\begin{abstract}
Husserl, as is well known, bases his study of appearing on subjective functions. He also makes appearing prior to being insofar phenomenology grants being to entities only to the point that they can appear. Both positions result in the paradox that he presents in the Crisis, where he asks: "How can human subjectivity, which is a part of the world, constitute the whole world, i.e., constitute it as its intentional product...? The subjective part of the world swallows up, so to speak, the whole world including itself. What an absurdity!". The paradox arises from Husserl's taking being as presence and asserting that presence is esta-blished through constitution and, as such, is the work of subjectivity. In this article, I explore an alternative based on Aristotle's concept of functioning. This is a functioning that is prior to both subjects and objects, a functioning that is responsible for both being and appearing. The introduction of this concept, I argue, does not change Husserl's description of the functioning of constitution. It does, however, add an ontological basis that prevents phenomenology from falling into this paradox.
\end{abstract}

Keywords: Husserl. Aristotle. Constitution. Energeia (Functioning). Ontology. Phenomenology.

\begin{abstract}
Resumen: Husserl, como es bien sabido, basa su estudio del aparecer en funciones sujetivas. También presenta el aparecer como anterior al ser en tanto en cuanto la fenomenología le concede ser a las entidades sólo hasta el punto de que puedan aparecer. Ambas posiciones dan como resultado la paradoja que presenta en $L a$ crisis, donde pregunta: "¿Cómo puede la subjetividad humana, que es parte del mundo, constituir el mundo entero, es decir, constituirlo como su producto intencional...? La parte subjetiva del mundo se traga, por así decirlo, todo el mundo, incluido él mismo. iQué absurdo!". La paradoja surge del hecho de que Husserl toma el ser como presencia y de que afirma que la presencia se establece a través de la constitución y que, como tal, es el trabajo de la subjetividad. En este artículo, exploro una alternativa basada en el concepto de funcionamiento de Aristóteles. Este es un funcionamiento que es anterior a ambos sujetos y objetos, un funcionamiento que es responsable de ser y aparecer. La introducción de este concepto, sostengo, no cambia la descripción de Husserl del funcionamiento de la constitución. Sin embargo, agrega una base ontológica que evita que la fenomenología caiga en esta paradoja.
\end{abstract}

Palabras clave: Husserl. Aristóteles. Constitución. Energeia. Ontología. Fenomenología. 
Husserl, as is well known, bases his study of appearing on subjective functions. He seeks to know how being appears by examining how the subject functions to constitute this appearing. Such constitution embraces the very framework of appearing insofar as it includes the syntheses that make present both space and time. The question that this project raises involves the ontological status of such functions and, ultimately of subjectivity itself. What is the subject's relation to the world that it constitutes? Does not the very assertion of such constitution involve us in a part-whole paradox? Thus, Husserl asks:

How can human subjectivity, which is a part of the world, constitute the whole world, i.e., constitute it as its intentional product...? The subjective part of the world swallows up, so to speak, the whole world including itself. What an absurdity! ${ }^{1}$

The difficulty concerns the ontological status of the subject, in Husserl's words, the fact that it possesses "both the being of a subject for the world and the being of an object in the world"2. How can something in the world constitute the world and, hence, itself as part of the world? This question receives its urgency from phenomenology's making appearing prior to being. Thus, phenomenology grants being to entities only to the point that they can appear. Without such appearing, there is no evidence for their positing ${ }^{3}$. To deny this is, Husserl implies, to slip into "an unconfessed metaphysics", one that makes ontological assumptions that cannot be phenomenologically justified ${ }^{4}$. This view seems to take being as presence. But presence is established through constitution. It is the work of subjectivity ${ }^{5}$. Are we not, thus, led to the paradox of a part of the world being responsible for the whole of the world and, hence, for itself?

Husserl, of course, has an answer for these questions-one that involves the conception of an ultimately functioning subjectivity that is responsible both for the world and the subjects that inhabit it. In this paper, I am going to explore an alternative based on Aristotle's concept of functioning. This is a functioning that

${ }^{1}$ Die Krisis der Europäischen Wissenschaften und die transzendentale Phänomenologie, Ed. W. Biemel, The Hague: Martinus Nijhoff, $1962^{2}$, p. 183). All translations from the German in this paper are my own.

${ }^{2}$ Ibid., p. 182.

${ }^{3}$ The ultimate premise here is the priority of epistemology (the science of knowing as based on evidence) over metaphysics. According to Husserl, "Epistemology must not be taken as a discipline which follows metaphysics or even coincides with it; on the contrary, it precedes it as it does psychology and every other discipline" (Logische Untersuchungen, hereafter referred to as $L U, 3$ Vols., Tübingen: Niemeyer $1968^{5}$, I, p. 224).

${ }^{4}$ Cartesianische Meditationen, Ed. S. Strasser (The Hague: Martinus Nijhoff, 1963), p. 174.

${ }^{5}$ This holds not just for spatial temporal real objects, but also for ideal, non-spatial temporal objects. The presence of the latter is the result of categorial intuition. 
is prior to both subjects and objects, a functioning that is responsible for both being and appearing. What I am going to do is attempt to think phenomenology in terms of such functioning.

\section{BEING AS FUNCTIONING}

Aristotle's term for functioning is energeia. He coined it out of two words, en and ergon. It means literally "at work" and is sometimes translated as being in act and, hence, as actuality. Actuality has, of course, a verbal sense of acting. It also, however, has an ontological connotation. This can be put in terms of the etymological sense of the term "existence", which is that of standing out-ex and istimi in the Greek. Things stand out, that is, ex-ist, by acting on and, hence, affecting their environment. On the most basic level, living beings do this through engaging in metabolism, i.e., by exchanging material with what surrounds them. Inanimate objects do this through the vibration of atoms, the movement of electrons, the flux of subatomic particles, and so on. Without such actions, entities could not distinguish themselves from their environments; they could not affect them. Environmentally, they would be indistinguishable from non-entities. This holds not just objectively, but also subjectively. For example, when I stumble on an object in a dark room, the object stands out. It exists for me. The same holds, when I posit it, not directly, but through its influence on its environment, for example, when from the footprint, I deduce that someone has taken a path.

This conception of energeia immediately links being and presence. If the ontological sense of being involves at-workness, then being, through its working on its environment, is present to it. Such presence, it should be emphasized, is not, in the first instance, conceived subjectively, i.e., taken as presence to us. It is a perfectly general term, involving as it does, every possible environment. The crucial fact in such presence is that it consists in the being-at-work of the entity. If we combine this with the fact that to be is to be at work, then we have to say with Aristotle that the entity that is at work is where it is at work. In other words, the at-workness that makes it be is located at the very place of its action. Thus, for Aristotle, "the functioning (energeia) of the sensible object" is "in the sensing subject" 6 . It is where the perception of the object is actually operative. In fact, it

\footnotetext{
${ }^{6}$ De Anima, III, 2, 426a10. My translation.
} 
is "one and the same" with the functioning of such perception7. The same holds, according to Aristotle, for the functioning of the teacher. The functioning is "teaching", and the place of this is where it is presently at work, i.e., "in the one taught" 8 . It is there as the operation or functioning of his power to have the learner learn. Given that the functioning of teaching requires that of learning, what we have are not two different functionings, but rather aspects of a single functioning, one which requires both teacher and learner. Another way of putting this point is to note that the functioning of the learner is his own and yet is received. His receptivity to the at-workness of his teacher is one with his beingat work-learning. The same holds for the functioning of the seeing eye. Its receptivity to the functioning of the visible object is one with its activity of seeing.

If we accept this view then functioning is neither objective nor subjective. The same holds for the presence of such functioning and, indeed, for the phenomenological sense of such presence. The phenomenology that results is such that we avoid the dilemma that confronted Descartes when he wrote "this alien entity sends to me and imposes upon me its likeness" ${ }^{\prime \prime}$. The difficulty, in Descartes' words, is how I could ever know whether "the ideas [the sensuous perceptions] which are in myself are similar to, or conformable to, things outside myself?"10. From an Aristotelian perspective, this question makes no sense since the actuality (the functioning) of the perceived is its manifestation through our perception. In other words, if Aristotle is right in asserting that the sensible object as sensible is actually one with its being sensed, there is no original out there with which we could compare our perception. Given this, the phenomenology that studies appearing has as much right to call itself objective as subjective.

\section{SPACE AND TIME}

To say that the teacher is in the student seems counter factual. It violates our sense that to be is to be in a definite place at a definite time. Descartes captured this sense in the Cartesian grid he employed in his analytic geometry, a grid that allows us to number and mathematically describe figures on a plane.

\footnotetext{
${ }^{7}$ Ibid., 425b27. My translation.

8 Physics, 202b 7-8. My translation.

${ }^{9}$ Meditations on First Philosophy, trans. L. LaFleur, New York: Macmillan, 1990, p. 37.

10 Ibid., p. 36.
} 
If we add a third, depth dimension and an axis delineating time, we have a set of axes and numerical co-ordinates that allow us to write formulae for definite positions, paths, and movements in spatial-temporal reality. Where would we locate the teacher in such a grid? From an Aristotelian perspective, the teacher is wherever her functioning has effect. Writing at the blackboard, pushing the chalk along, she is at the place of this physical functioning. Speaking and setting up the movements of perception and understanding, she is also present in her students' perceiving and learning. In her books, she is present wherever and whenever she causes someone to grasp her meaning. As is obvious, the attempt to think of presence in terms of energeia demands that we abandon the definite description that the Cartesian grid permits. It, thus, leaves us with the tasks of conceiving space, time and movement in terms of energeia.

Aristotle writes, "the functioning of what is potential as potential, that is "being in movement"11. To illustrate this, he refers to the building of a house, writing, "when building materials [...] are actually functioning as building materials, there is something being built; and this is [the movement] of building"12. Now, they function as such when something is being built. There is, in building, a transformation of the building materials that realizes something beyond then-namely, a house. Thus, Aristotle adds: "[t]he functioning [...] of what is potential, where there is something being realized, not as itself, but as movable, is motion"13. For example, "the functioning of bronze 'as' bronze is not sufficient. Being bronze and being made into a bronze statue are not the same. What we need is the functioning of its capacity (or power) to be made into a statue. Explaining this, he adds: "For any power may sometimes function and sometimes not, for example, building materials; their functioning as building materials is the process of building" ${ }^{\prime 14}$.

The Greek word for functioning in this translation is entelechia, which also signifies "actualization". Motion, then, is the realization of something through the actualization of a given potentiality, for example, the realization of a house through the actualization of the capacity of the building materials to be made into a house. The same can be said of the relation of the teacher to the student.

${ }^{11}$ Physics, 201a 10-15, Aristotle's Physics, trans. Richard Hope, Lincoln, Nebraska: University of Nebraska Press, 1961, p. 42. This text will be cited as Physics. Hope trans.

${ }^{12}$ Ibid., 201a 16. Hope trans., p. 42.

13 Ibid. , 201a 29. Hope trans., p. 42.

${ }^{14}$ Ibid., 201b 9. Hope trans., p. 43. 
The student's learning is the actualization of his capacity to learn. What actualizes him is the at-workness, the energeia of the teacher. Here, the student is, so to speak, the material that the teacher works on. To reverse this, we can say that the teacher is herself actualized by the student. His questions, his attempts to actively learn work on the teacher. Each then works on the other, each serves as material for the other. The single functioning in the sense of energeia thus results in their mutual actualization.

To understand space in these terms is, according to Aristotle, to understand it in terms of motion ${ }^{15}$. Aristotle understands space as place and defines place as "the first unmoved boundary of what surrounds [the entity]"16. Place answers to the question, "where", and the answer to this depends on the entity's motion. Thus, if I am seated writing at my desk, I am in my chair. If I get up and walk about my office, its walls are my first unmoved boundary. If I now pace the hallway, perhaps visiting other offices on the second floor, the appropriate answer to the question "where" is "on the second floor". If I take the elevator and visit other floors, my "where" is the building itself. Similarly, during the day, I am at the university; during the week, I am in this city, and so on. The point is that the entity itself determines through its motion its first unmoving boundary and, hence, what constitutes the limits of its environment ${ }^{17}$. This definition of place can be expanded beyond the physical presence caused by local motion. The place of the teacher is not just a result of the functioning of her ability to move about. It is, as we said, also an effect of her ability to teach. As such, her place is wherever her teaching is at-work, i.e., wherever it actualizes the student's ability to learn.

Aristotle's concept of place is very different from the modern view of space, which takes it as a receptacle into which things can be put. We tend to think of space as independent of entities-as a void that can continue to exist even when nothing fills it. For Aristotle, by contrast, an empty space or "void", is impossible.

\footnotetext{
${ }^{15}$ Aristotle writes, "we must keep in mind that, but for local motion, there would be no place as a subject matter of investigation". Physics, 211a 13. Hope trans., p. 64.

${ }^{16}$ Ibid., 212a 20. Hope trans., p. 66.

${ }^{17}$ Only if we ignore the issue of motion can we define "place" as the interface between the body and what immediately surrounds it. Once we do consider motion, then as Aristotle notes, this definition has to be modified. We have to say that "place is a receptacle which cannot be transported" (Physics, $212 a 15$. Hope trans., p. 65). Thus, the place of a motionless boat is given by the surrounding water, but once we consider the boat as moving down the river, "it is the whole river which, being motionless as a whole, functions as a place" (ibid., 212a 19. Hope trans., p. 66). As the example of the boat suggests, the place of a body need not be continuous with the body itself.
} 
Considered in itself, it is a kind of "nonbeing or privation", which means that we can no more characterize it positively than we can find "differences in nothing"18. Rather than being such a void, place is always occupied. It is not independent, but rather depends on the entities that define it. It is, for Aristotle, a function of their at-workness. More precisely, it is, as their "first unmoved boundary", the presence of their at-workness.

Aristotle makes the same points with regard to time. Like place, it is not an independent reality. It is rather a result of the at-workness of entities. Apart from this, it is nothing at all. Thus, considered by itself, a stretch of time "consists in non-beings" since it "comprises the past, which no longer is, and the future, which is not yet"19. As for the present or the now, it is not a part of time since "a part is a measure of the whole, whereas the present is not such a measure". Given this, we cannot say that time is "composed of nows"20. The necessity for this is more than the logical point that no number of atomic (partless) nows can be summed to produce an extended whole. It follows from the fact that time, like place, is not a substance in the Aristotelian sense: it is not something that exists on its own. Its actualization requires the at-workness of something else, which is not a part of time, but prior to it. This is the entity, whose presence is what time manifests. The present or the now that is not a part of time is the entity's constant presence to the soul ${ }^{21}$. This presence is one with the entity's actualization of the soul's potential to be receptive to the entity. Such actualization is brought about by the at-workness of the entity. As in the case of place, what is crucial here is motion. It is not the entity's presence pure and simple that actualizes time but rather the change of its presence. Thus, the temporal result of an unchanging presence would be an unchanging present or constant now. But as Aristotle observes, "there would be no time" if there were "only a single, self-identical present"22. This follows since "when we have no sense of change [...] we have no sense of the passing of time ${ }^{\prime 23}$. The entity, then, manifests itself as time through the change of its presence.

${ }^{18}$ Ibid., 215a 11. Hope trans., p. 72.

${ }^{19}$ Ibid., 218a 2. Hope trans., p. 77.

${ }^{20}$ Ibid., 218a 7-8. Hope trans., p. 78.

${ }^{21}$ Failure to grasp this point makes Aristotle's derivation of time circular. If the present is part of time, then to use it to derive time from motion by noting the different presents (nows) associated with the different positions of the moving body is to derive time from itself.

22 Physics, 218b 28. Hope trans., p. 79.

${ }^{23}$ Ibid., 218b 24. Hope trans., p. 79. 
This does not mean that this presence exhibits a sheer otherness. It combines both identity and difference. The identity comes from the identity of the entity whose presence it is. The difference stems from the differences created by the entity's movement. As Aristotle writes: "The moving body [...] is the same [...] but the moving body differs in the account which may be given of it". In particular, it differs by being in different places "and the present corresponds to it as time corresponds to the movement" ${ }^{\prime 24}$. This means that the present or now which "is not a part of time" is the unchanging presence of the body. This present "corresponds" to the body by virtue of being part of the body's continuous selfmanifestation, its continuous actualization of the capability of the soul to be receptive. The continuity of time depends upon this continuity, this lack of any gaps in the body's presence ${ }^{25}$. Similarly, the movement of time corresponds to the body's movement insofar as it manifests the body's shifting relation to its environment. Thus, "it is by reference to the moving body that we recognize what comes before and after in the movement" 26 . We say, "before, the body was here, afterward, it was there".

If, on reflection, we distinguish the before from the after, then the present appears as a division between the two: it is the presence of the body after it left one place and before it went to another. With motion comes the shift of the before and the after and, with this, the appearance of the flowing present or now. This shifting center of the temporal environment is simply a dimension (an attribute, an aspect) of the presence of the body as the shifting center of its environment. Time, thus, appears as a kind of stationary streaming. We experience it as a flow, that is, as a constant succession of the "before and after". Yet, we also have to say that the present in which we experience this streaming is itself stationary and remaining. It is not part of time in the sense that it departs with its fleeting moments. Rather, it is always now for us. The constancy of this now is the constancy of the presence of the entity. We experience it as long as we are aware of the entity or, what is the same, as long as the entity is at work, manifesting itself to us. Our experience of time is, thus, the result of a duality in the presence

${ }^{24}$ Physics, 219b 20-23. Hope trans., p. 81.

25 The same point can be made about the continuity of motion. As Aristotle writes in On Generation and Corruption, motion is not continuous "because that in which the motion occurs is continuous", but rather "because that which is moved is continuous. For how can the quality be continuous except in virtue of the continuity of the thing to which it belongs?" (337a 27-29. My translation).

${ }^{26}$ Physics, 219b 24. Hope trans., p. 81. 
of the moving body. The constant presence of the body that moves works on us such that we experience the constant now, while the shifting presence of its environment modifies the result so that we experience this now as shifting, i.e., as the now through which time seems to stream.

If we accept Aristotle's view of space and time, then we cannot see them as an independent framework for appearing. They are the result of the being-at work of entities on their environment. Such being-at-work or energeia brings about the space and time through which spatial-temporal beings appear. Space and time here can be considered abstractly as materials for such appearing. They do not themselves appear. When actualized by the entity, they are part of its appearing. In this, they are like Aristotle's bronze being made into a statue: "Being bronze and being made into a bronze statue are not the same. What we need is the functioning of its capacity (or power) to be made into a statue". Similarly, space and time require the functioning (the actualization) of their capacity to be that through which entities appear. Thus, in the absence of a soul to register motion, there would be no time. Only motion-understood as a sheer change-would remain ${ }^{27}$. In the absence of motion, not just time but also place would vanish ${ }^{28}$.

\section{THE TRANSFORMATION OF PHENOMENOLOGY}

Phenomenology taken in the broad sense is not just the study of appearing. It also embraces the subject to whom things appear. Both are transformed by Aristotle's concept of energeia. Appearing becomes the presence of being. It is the result of its being-at-work on us. What we have here is the reverse of Husserl's assertion that such being is "according to its sense merely intentional being. [...] It is a being that consciousness posits in its experiences [...] beyond this, however, it is nothing at all"29. In this view, consciousness and its synthetic activity is first, the entity itself is second. As Husserl puts this, "the existence

\footnotetext{
27 See ibid., 223a 25-29. Hope trans., p. 87.

28 Patočka puts this point as follows: "Considered as originally given, space and time are distinct dimensions of 'movement' and 'modification'; they are dimensions that are each time different [depending on the movement]. Taken as dimensions of the 'change' that provides the basis for both, they are only developments of the 'possibility' of movement or modification. They do not become actual space or time except through an actual movement or modification". "Phénoménologie et ontologie du mouvement", in Papiers Phénoménologiques, trans. Erika Abrams, Grenoble: Jérôme Millon, 1995, p. 38. My translation.

${ }^{29}$ Ideen zu einer reinen Phänomenologie und phänomenologischen Philosophie, Erstes Buch, Ed. W. Biemel, The Hague: Martinus Nijhoff, 1950, p. 117.
} 
(Dasein) of the thing itself, the object of experience, is inseparably implicit in this system of transcendental connections [between experiences]". His claim is that "without such connections, it would, thus, be unthinkable and obviously a nothing" ${ }^{\prime \prime}$. Such assertions lead us to the paradox we began with: that of a part of the world constituting the whole of the world and, hence, itself ${ }^{31}$. The reversal consists not in denying that the presence of being demands the connections of experiences, which arise through our acts of synthesis. It comes in our seeing such acts as a functioning that embraces both the subject and object. In other words, the functioning of the subject as that-to-whom being appears in continuity with the functioning of the being that appears.

We can see this continuity in the fact that the functioning of the subject that apprehends time determines its being as a stationary streaming now. Husserl, we should note, describes the subject in similar terms. He writes that through the phenomenological reduction,

we come to the never before presented, let alone systematically interpreted 'primal phenomenon', in which everything has its origin that may in any sense be called a phenomenon. This is the stationary-streaming self-present or the self-streaming, present absolute ego in its stationary-streaming life. ${ }^{32}$

For Husserl, this "stationary-streaming self-present", or now, is an absolute origin. From an Aristotelian perspective it is actualized by the presence of being. Its functioning as stationary is one with the continuity of the presence of being; its functioning as flowing is one with the shift of such presence occasioned by motion. Like the student's learning in relation to the teacher's teaching, we can speak of the functioning of this stationary streaming self-present as our own and yet received. From an Aristotelian perspective, it is neither subjective nor objective but rather part of a single functioning.

${ }^{30}$ Erste Philosophie (1923/24), Zweiter Teil: Theorie der phänomenologischen Reduktion, Ed. R. Boehm, The Hague: Martinus Nijhoff, 1959, p. 404.

${ }^{31}$ Such a conclusion becomes inevitable once we assert that through phenomenology "every sort of being itself (Seiendes selbst), be it real or ideal, becomes understandable as a constituted product (Gebilde) of transcendental subjectivity, a product that is constituted in just such an [subjective] accomplishment". Cartesianische Meditationen, p. 118.

32 "So stoßen wir bald vor auf das nie herausgestellte, geschweige denn systematisch ausgelegte 'Urphänomen', in dem alles, was sonst Phänomen heißen mag und in welchem Sinn immer, seine Quelle hat. Es ist die stehend-strömende Selbstgegenwart bzw. das sich selbst strömend gegenwärtige absolute Ich in seinem stehend-strömenden Leben". Ms. C 7, p. 38a, June 1932, in Späte Texte über Zeitkonstitution [1929-1934], Die C-Manuskripte, Ed. Dieter Lohmar, Dordrecht: Springer Verlag, 2006, p. 145 
The same points can be made with regard to perception. Perception, according to Husserl is a teleological process. It is guided by a goal, that which we intend to see. This intention guides our interpretation of what we actually do see. We can see it at work whenever we regard optical illusions-drawings cleverly designed to support different interpretations. Take, for example, the illusion that seems to show us either a young girl or an old woman. As we shift between the two, what changes is not the data of the page but our interpretation of what they present. The shift of interpretations is a shift in what we intend to see. This determines our actual perception. To take another example, suppose we see what seems to be a cat hiding under a bush. Moving closer, its features seem to become more clearly defined. One part appears to be its head, another its body, still another its tail. Based upon what we see, we anticipate that further features will be revealed as we approach: this shadow will be seen as part of the cat's ear; another will be its eye, and so forth. As in the case of the optical illusion, what we intend to see determines how we regard what we have seen. It makes us take it as material for our "project" of seeing a specific object. Given that what we intend to see as we move to get a better look is not yet fully there, it stands as a goal of the perceptual process. Such goal directed activity characterizes constitution generally. It is also present in all our practical projects, where what we intend to accomplish determines our present activity.

From a Cartesian perspective, which dismisses the concept of final causes, such activity is inexplicable. For Aristotle, however, goal directed activity follows from the concept of energeia. He asserts that

everything that comes to be moves towards its source ( $\left.\dot{\varepsilon} \pi^{\prime} \dot{\alpha} \rho \chi \eta^{\prime} v\right)$, that is, towards its goal ( $\tau \dot{\varepsilon} \lambda \circ \varsigma$ ); for its wherefore [its final cause] is its source. Its coming into being is directed by the end, which is being-at-work ( $\dot{\varepsilon} v \varepsilon \dot{\rho} \rho \varepsilon 1 \alpha$ ), and it is thanks to the end that potentiality ( $\delta$ v́vats) is possessed. ${ }^{33}$

Thus, in the process of perception the goal is given by the object. Its beingat-work (energeia) actualizes the potentiality that allows it to come to presence. The very same being-at-work yields the space and time that frame the entity's appearing. As inherent in appearing, they are actualized along with the syntheses that make the object present to the subject. In a certain sense, we can say that

33 Metaphysics IX, VIII, 1050a 8-10. My translation. 
the introduction of the concept of energeia changes nothing in Husserl's description of perception. What it does do, however, is to add an ontological basis that prevents phenomenology from falling into the paradox I began with ${ }^{34}$. We are no longer faced with a "subjective part of the world" swallowing "up, so to speak, the whole world including itself". Instead, we have the conception of both the subject and the world it brings to presence as engaged in single, mutual functioning.

34 This ontological basis is apparent in Patočka's position, which is heavily influenced by Aristotle. Patočka writes: "There is not an identity because I synthesize, but I synthesize because I place my finger on an identity. Change, process, transformation are themselves identifications; they are material syntheses. My subjective synthesis of identification is simply the grasp, the recognition of this singular identity, this inner connection of things. There is not simply a chaos of phases, of moments, of aspects in a thing. There is their real connection, their interpenetration, their combination [...]". "Phénoménologie et ontologie du mouvement", p. 32. 